\title{
COVID-19 associated with onset nephrotic syndrome in a pediatric patient: coincidence or related conditions?
}

\author{
Amado Alvarado ${ }^{1} \cdot$ Gabriela Franceschi $^{1} \cdot$ Evelin Resplandor $^{1} \cdot$ Jeannethe Sumba ${ }^{1} \cdot$ Nelson Orta $^{2} \mathbb{C}$
}

Received: 15 July 2020 / Accepted: 23 July 2020 / Published online: 27 August 2020

(C) IPNA 2020

\begin{abstract}
Background COVID-19 is less frequent in children than in adults and affects the former less severely; despite the fact that respiratory symptoms are the most frequent, in some cases unusual manifestations can be seen.

Case-diagnosis We present a 15-year-old boy who tested positive for SARS-COV-2 infection and onset of nephrotic syndrome, without antecedent of kidney disease and who had normal urine tests shortly before being affected by COVID-19.

Conclusions The patient described in this report, who was admitted due to nephrotic syndrome and respiratory syndrome, tested positive for COVID-19. He, based on the data review by the researchers, is the first reported case of COVID-19 with simultaneous onset of complete picture of nephrotic syndrome. The presence of both diagnoses could be a coincidence or an unusual form of presentation of COVID-19.
\end{abstract}

Keywords Covid- $19 \cdot$ Nephrotic syndrome $\cdot$ SARS-COV-2 $\cdot$ Proteinuria $\cdot$ Adolescent

\section{Introduction}

The pandemic of coronavirus disease (COVID-19) represents a multi-faceted challenge for health systems across the globe, including on issues related to diagnosis. Respiratory manifestations are the predominant presentation of COVID-19 among symptomatic patients; additionally, it is relevant to emphasize that multiple organ involvement, including the gastrointestinal tract, central nervous system, cardiovascular system, liver, bone marrow, and kidney, has been reported in patients infected with SARS-CoV-2 [1,2]. As to viral tropism, the lungs are not the only COVID-19 target, but the kidneys also may be involved in a significant percentage of infected patients, particularly in those severely affected [3]. When compared with adults, COVID-19 is less frequent in the pediatric population, and typically presents respiratory syndrome $[1,4]$; however, the virus can produce unusual manifestations in children, e.g., Kawasaki's disease and gastrointestinal syndrome, and

Nelson Orta

nelson.orta@gmail.com

1 General Hospital, Ecuatorian Institute of Social Security, IESS, Quito, Ecuador

2 University of Carabobo, Valencia, Venezuela epidemiological studies have shown that children are at lower risk of critical illness $[1,2,5]$.

Information about COVID-19 in children with nephropathies is lacking; a report from Spain described 16 patients with chronic kidney diseases presenting mild respiratory symptoms and few radiological manifestations. Of these, glomerular filtration worsened in three, and two patients with steroiddependent nephrotic syndrome had relapse [6].

Isolated nephrological manifestations in COVID-19 have also been reported: hematuria in a pediatric case [7] and hematuria and albuminuria in critical patients, suggesting an association of COVID-19 with nephritis glomerular changes [8]. Nephritis-like histology was also described in postmortem samples from patients with COVID-19 [9].

Herein we describe a case of SARS-CoV-2 infection presenting with a complete picture of onset of nephrotic syndrome along with respiratory symptoms in a pediatric patient.

\section{Case report}

A 15-year-old boy was admitted in April 2020 with fever, generalized edema, myalgias, and oliguria. In a matter of hours, he developed progressive dyspnea, was diagnosed with nephrotic syndrome (anasarca, hypoalbuminemia, proteinuria, 
and hyperlipidemia), and tested positive for SARS-CoV-2 infection.

Antecedents: urinary tract infection in infancy, vomiting, and diarrhea 3 months prior with recurrence one month later; urine tests were normal during both evaluations.

At admission: weight: $55 \mathrm{~kg}$, height: $167 \mathrm{~cm}$, blood pressure: $140 / 70 \mathrm{mmHg}$, moderate intercostal retraction, mild ascites, pain in left knee. Urine test: protein +++, no hematuria, $\mathrm{Hb}: 12.8 \mathrm{~g} / \mathrm{dl}$, HTC: $33.6 \%$, total protein: $3.9 \mathrm{mg} \%$, albumin: $1.5 \mathrm{mg} \%$, leukocytes: $5600 / \mathrm{mm}^{3}$, platelets: $224.000 / \mathrm{mm}^{3}, \mathrm{Cl}^{-}: 102, \mathrm{~K}^{+}: 5, \mathrm{Na}^{+}$: 135 , serum creatinine: $0.55 \mathrm{mg} \%$, alkaline phosphatase: $85, \mathrm{~T}$ calcium: $7 \mathrm{mg} \%, \mathrm{Mg}^{+}: 2 \mathrm{mg} \%$, phosphorus: $2.7 \mathrm{mg} \%$, triglycerides: $240 \mathrm{mg} \%$, cholesterol: $202 \mathrm{mg} \%$, glucose: $101 \mathrm{mg} \%$, arterial blood gases: $\mathrm{pH}: 7.44, \mathrm{HCO}_{3}: 21 \mathrm{meq} / \mathrm{L}, \mathrm{O}_{2}$ Sat: $95 \%$.

$(r R T-P C R)$ for SARS-CoV-2 infection: positive. D Dimer initial: $32.074 \mathrm{ng} / \mathrm{mL}$ (ELFA) (reference value $(\mathrm{RV})$ : < 500) and four weeks later: $1385 \mathrm{ng} / \mathrm{dL}, \mathrm{IL}-6: 17.1 \mathrm{pg} / \mathrm{mL}$ (EQLM) (RV: <7), LDH: 743 U/L (RV: 120-300), CPK: 583 U/L (RV: 0-270), C3: $53 \mathrm{mg} / \mathrm{dL}$ (RV: 90-180), C4: $4 \mathrm{mg} / \mathrm{dL}$ (RV: 10-40), ANCAc: $1.5 \mathrm{U} / \mathrm{mL}(\mathrm{RV}:<5)$, ANCAp: $1.6 \mathrm{U} / \mathrm{mL}$ (RV: <5), ANA (IF): $1320 \mathrm{U} / \mathrm{mL}(\mathrm{RV}:<1.8)$, Ac anticardiolipin: $-5.6 \mathrm{GPLU} / \mathrm{mL}(\mathrm{RV}:<10)$, Ac anticardiolipin IgM: 14.7 0MPLU/mL (RV: <7), Ac antiB2glycoprot IgG: $3.70 \mathrm{U} / \mathrm{mL}(\mathrm{RV}:<5)$, Ac antiB2glycoprot IgM: $15.30 \mathrm{U} / \mathrm{mL}(\mathrm{RV}:<5)$, hepatitis C and $\mathrm{B}$ : negative, hemoculture (3): negative, 24 -h proteinuria: $4 \mathrm{~g} / 24 \mathrm{~h}$. Chest/lungs X-ray and CT scan: bilateral pleural effusion and reticular interstitial opacity in lungs. Treatment: chloroquine and azithromycin, daily boluses of methylprednisolone $\times 5$. The patient's respiratory syndrome and edema improved and kidney biopsy will be undertaken when possible.

\section{Discussion}

Kidney injury has been described in viral respiratory infections including adenovirus, influenza $\mathrm{A}$ and $\mathrm{B}$, and other pathogens. Kidney injury in patients severely affected with COVID-19 appears to be a frequent finding, with a wide range of manifestations, from microhematuria, isolated proteinuria, elevation of azotemia products in serum, and severe acute kidney injury $[3,7]$. However, based on the data review by the researchers, a complete nephrotic picture has not been reported.

The pathogenesis of the kidney damage could be multi-factorial, including direct cytopathic effects of the virus, immune complex-mediated damage, and secondary systemic effects on kidney tissue, such as hypovolemia, hypoxia, and shock, due to the cytokine inflammatory response to the virus [3].

It has been suggested that the multi-organ manifestations of COVID-19 are the consequence of angiotensinconverting enzyme 2, the receptor for SARS-CoV-2, which is responsible for host cell entry and subsequent viral replication in humans, and is broadly expressed in tissue of the alveolar epithelial cells, the myocardium, the endothelium, the gastrointestinal tract, bone marrow, kidneys, among other tissues [10].

One of the most striking features of COVID-19 is the overwhelmingly lower risk of severe forms of disease in children when compared with older age groups [6]. To date, there are few reported cases of kidney involvement in children with COVID-19 [5].

In summary, the patient described in this report with no history of chronic kidney disease, admitted because of nephrotic syndrome and respiratory syndrome, and tested positive for COVID-19. As far as we know, this is the first reported case of COVID-19 with simultaneous onset of nephrotic syndrome; this could be either a coincidence or an unusual form of presentation of COVID-19. Pediatricians should be aware of this possibility when treating children, and test them for proteinuria, serum proteins, and blood lipids to diagnose the nephrotic condition of patients.

\section{Compliance with ethical standards}

Conflict of interest The authors declare that they have no conflicts of interest.

Informed consent Informed consent was obtained from the parents.

\section{References}

1. Chao JY, Derespina KR, Herold BC, Goldman DL, Aldrich M, Weingarten J, Ushay HM, Cabana MD, Medar SS (2020) Clinical characteristics and outcomes of hospitalized and critically ill children and adolescents with coronavirus disease 2019 (COVID-19) at a tertiary care medical center in New York City. J Pediatr 223:14 19.e2. https://doi.org/10.1016/j.jpeds.2020.05.006

2. Huang C, Wang Y, Li X, Ren L, Zhao J, Hu Y, Zhang L, Fan G, Xu J, Gu X, Cheng Z, Yu T, Xia J, Wei Y, Wu W, Xie X, Yin W, Li H, Liu M, Xiao Y, Gao H, Guo L, Xie J, Wang G, Jiang R, Gao Z, Jin Q, Wang J, Cao B (2020) Clinical features of patients infected with 2019 novel coronavirus in Wuhan, China. Lancet 395:497-506

3. Cheng Y, Luo R, Wang K, Zhang M, Wang Z, Dong L, Li J, Yao Y, Ge S, Xu G (2020) Kidney disease is associated with in-hospital death of patients with COVID-19. Kidney Int 97:829-838

4. Castagnoli R, Votto M, Licari A, Brambilla I, Bruno R, Perlini S, Rovida F, Baldanti F, Marseglia GL (2020) Severe acute respiratory syndrome coronavirus 2 (SARS-CoV-2) infection in children and adolescents. A systematic review. JAMA Pediatr. https://doi.org/ 10.1001/jamapediatrics.2020.1467

5. Safadi MAP (2020) The intriguing features of COVID-19 in children and its impact on the pandemic. J Pediatr 96:265-268. https:// doi.org/10.1016/j.jpedp.2020.04.001

6. Melgosa M, Madrid A, Alvárez O, Lumbreras J, Nieto F, Parada E, Perez-Beltrán V, Spanish Pediatric Nephrology Association (2020) SARS-CoV-2 infection in Spanish children with chronic kidney pathologies. Pediatr Nephrol. https://doi.org/10.1007/s00467-02004597-1 
7. Almeida FJ, Olmos RD, Oliveira DB, Monteiro CO, Thomazelli LM, Durigon EL, Sáfadi MAP (2020) Hematuria associated with SARS-CoV-2 infection in a child. Pediatr Infect Dis J 39:e161. https://doi.org/10.1097/INF.0000000000002737

8. Gross O, Moerer O, Weber M, Huber TB, Scheithauer S (2020) COVID-19-associated nephritis: early warning for disease severity and complications? Lancet. https://doi.org/10.1016/S01406736(20)31041-2

9. Su H, Yang M, Wan C, Yi LX, Tang F, Zhu HY, Yi F, Yang HC, Fogo AB, Nie X, Zhang C (2020) Renal histopathological analysis of 26 postmortem findings of patients with COVID-19 in China. Kidney Int. https://doi.org/10.1016/j.kint.2020.04.003

10. Hamming I, Timens W, Bulthuis ML, Lely AT, Navis G, van Goor $\mathrm{H}$ (2004) Tissue distribution of ACE2 protein, the functional receptor for SARS coronavirus. A first step in understanding SARS pathogenesis. J Pathol 203:631-637

Publisher's note Springer Nature remains neutral with regard to jurisdictional claims in published maps and institutional affiliations. 